NBER WORKING PAPER SERIES

\title{
GROWING, SHRINKING, AND LONG RUN ECONOMIC PERFORMANCE: HISTORICAL PERSPECTIVES ON ECONOMIC DEVELOPMENT
}

\author{
Stephen Broadberry \\ John Joseph Wallis \\ Working Paper 23343 \\ http://www.nber.org/papers/w23343
NATIONAL BUREAU OF ECONOMIC RESEARCH
1050 Massachusetts Avenue
Cambridge, MA 02138 \\ April 2017
}

We would like to acknowledge helpful comments and suggestions from Bob Allen, Cormac Ó Gráda, Naomi Lamoreaux, Ethan Kaplan; Leandro Prados de la Escosura for his help with data sources; and seminars/workshops at Lund University, NYU Abu Dhabi, Queens University, the University of Maryland, the Cliometric Society meeting, the Economic History Association meeting, and the Economic History Society Conference. The views expressed herein are those of the authors and do not necessarily reflect the views of the National Bureau of Economic Research.

NBER working papers are circulated for discussion and comment purposes. They have not been peerreviewed or been subject to the review by the NBER Board of Directors that accompanies official NBER publications.

(C) 2017 by Stephen Broadberry and John Joseph Wallis. All rights reserved. Short sections of text, not to exceed two paragraphs, may be quoted without explicit permission provided that full credit, including (c) notice, is given to the source. 
Growing, Shrinking, and Long Run Economic Performance: Historical Perspectives on Economic Development

Stephen Broadberry and John Joseph Wallis

NBER Working Paper No. 23343

April 2017

JEL No. N0,N10,O0,O4,O43

\begin{abstract}
Using annual data from the thirteenth century to the present, we show that improved long run economic performance has occurred primarily through a decline in the rate and frequency of shrinking, rather than through an increase in the rate of growing. Indeed, as economic performance has improved over time, the short run rate of growing has typically declined rather than increased. Most analysis of the process of economic development has hitherto focused on increasing the rate of growing. Here, we focus on understanding the forces making for a reduction in the rate of shrinking, drawing a distinction between proximate and ultimate factors. The main proximate factors considered are (1) structural change (2) technological change (3) demographic change and (4) the changing incidence of warfare. We conclude with a consideration of institutional change as the key ultimate factor behind the reduction in shrinking.
\end{abstract}

Stephen Broadberry

Oxford University

Nuffield College

Oxford, OX1 1NF

United Kingdom

stephen.broadberry@nuffield.ox.ac.uk

John Joseph Wallis

Department of Economics

University of Maryland

College Park, MD 20742

and NBER

wallis@econ.umd.edu 


\section{INTRODUCTION}

Understanding long run economic performance is a fundamental concern of economists, economic historians and social scientists more generally. To date, most work in this area has focused on "growing", but recent work for the post-1950 period has suggested that economies vary as least as much in how they "shrink" as in how they grow (Easterly et al., 1993; Pritchett, 2000; Cuberes and Jerzmanowski, 2009). However, despite these findings on the volatility of GDP per capita in poor countries, there has been little research into why poor societies shrink so often or by so much. Furthermore, economic historians have not so far systematically investigated the possibility that improved long run economic performance since the eighteenth century could have been due to less shrinking rather than faster growing, despite the widespread acceptance of the idea that economic growth was slow during the Industrial Revolution (Crafts and Harley, 1992; Broadberry et al., 2015). In this paper, we show that to understand economic performance over the long run, economic historians, growth economists and development specialists must explain a reduction in the rate and frequency of shrinking rather than an increase in the rate of growing, a different problem from the one they normally address.

The key empirical findings reported here can be summarised as follows, where the growing rate refers to the average rate of change only during years of positive growth and the shrinking rate refers to the average rate of change only during years of shrinking (i.e. negative growth): (1) In most of the world since 1950, and historically for today's countries where data are available back to the thirteenth century, growing rates and shrinking rates have been high and variable. (2) When average growing rates have been high, average shrinking rates have also typically been high. Similarly, when average growing rates have been low, average shrinking rates have been low. (3) The improvement of economic 
performance over the long run has occurred primarily because the frequency and rate of shrinking have both declined, rather than because the growing rate has increased. (4) Indeed, as long run economic performance has improved over time, the short run rate of growing has normally declined rather than increased, but the frequency of growing has increased. In arithmetic terms, changes in growing rates by themselves would have led to lower rates of long term economic growth, ceteris paribus. To avoid misunderstanding, however, it is important to be clear that we do not dispute in any way that positive long run economic performance requires positive short run growing and that increases in short run growing rates contribute to positive long run economic performance. Rather, we draw attention to the under-appreciated role that economic shrinking has played both in the period since World War II and over the last millennium.

Despite this important role for a reduction in the rate and frequency of shrinking in the transition to modern economic growth in today's mature developed economies as well as in later developing countries, most analysis of the process of economic development has hitherto focused on increasing the rate of growing. Here, we make a start on redressing the balance by analysing the forces making for a reduction in shrinking, drawing a distinction between proximate and ultimate factors. The main proximate factors considered are (1)

structural change (2) technological change (3) demographic change and (4) the changing incidence of warfare. Institutional change is seen as the key ultimate factor behind the reduction in shrinking, bringing about the transition to modern economic growth.

\section{LONG- AND SHORT RUN ECONOMIC PERFORMANCE}

\subsection{Economic performance in the contemporary world}


We know that today's high income countries have had a better long run economic performance than today's low income countries since at least the early nineteenth century (Maddison, 2001; 2010). That fact is the essential motivation for growth theory, with its focus on the rate of growing. On closer examination, however, high income countries do not grow faster during their episodes of positive growth than poor countries grow during their episodes of positive growth. This can be demonstrated using information from the Penn World Table (PWT) for the period 1950-2011 (Feenstra et al., 2015). Table 1 from PWT 8.0 provides evidence on long run economic performance across groups of countries, broken down by level of income. The sample underlying the table includes 141 countries, with all included countries having data available from at least 1970 onwards. The data are arranged in five groups, ranging from high income countries with per capita incomes in the year 2000 greater than $\$ 20,000$ (in constant 2005 dollars), to poor countries with per capita incomes of less than $\$ 2,000$.

Table 1 makes use of an identity for establishing the contributions of growing and shrinking to long run economic performance. Long run economic performance can be measured by the rate of change of per capita GDP over periods of fifty years or longer. Economic performance over this time frame is the aggregation of short run changes measured at the annual level. Long-run economic performance, $g$, is a combination of 4 factors: (1) the frequency with which an economy grows, $f(+)(2)$ the rate at which it grows when growing, or the growing rate, $g(+)(3)$ the frequency with which an economy shrinks, $f(-)$ and (4) the rate at which it grows when shrinking, or the shrinking rate $g(-)$. Thus:

$$
g=\{f(+) g(+)\}+\{f(-) g(-)\}
$$

Since the frequency of growing is equal to one minus the frequency of shrinking, equation (1) can be rewritten as: 


$$
g=\{[1-f(-)] g(+)\}+\{f(-) g(-)\}
$$

which reduces the number of independent factors to three. We can use this identity to decompose long run economic performance into shrinking and growing components. We will show that better long run economic performance occurred not so much because of an increase in the growing rate, but more because of a reduction in the rate and frequency of shrinking. ${ }^{1}$

In Table 1, we see from the third column that poor countries have not grown less rapidly than rich countries when they have been growing. Indeed, the average growing rate has actually been higher for poorer countries than richer countries. Similarly, we can see in the final column that the average shrinking rate has also been higher for poorer countries. However, the second column shows that the frequency of growing has been higher for countries with higher levels of per capita income. The richest countries grew in approximately 84 per cent of years, while the poorest countries grew in just 62 per cent of years. Since the frequency of shrinking is one minus the frequency of growing, the frequency of shrinking has to be higher for poorer countries: the poorest countries shrank in almost 38 per cent of years, while the richest countries shrank in just 16 per cent of years. So poor countries have grown less frequently than rich countries; they have higher shrinking rates and shrinking frequencies.

Table 2 shows the contributions of growing and shrinking to long run economic performance. The contribution of growing to long run economic performance is the growing rate multiplied by the frequency of growing years. We see that most poorer countries had a stronger contribution from growing than economies with per capita incomes above $\$ 20,000$,

\footnotetext{
${ }^{1}$ We abstract from issues of timing. Over a fixed period of time, which is what we consider, when growing and shrinking occurs does not matter to the change in per capita income over the period. Substantively, however, the economy would be better off if growing occurred in the early years and shrinking in the later years rather than vice versa. Considerations of timing would make no difference to the calculations we perform.
} 
since the higher average growing rate of poorer countries more than offset the lower frequency of growing years. The only exception to this was the poorest category of countries with per capita incomes below $\$ 2,000$. These very poor countries had a weaker contribution of growing than the richest group of countries, but this was due to their lower frequency of growing years rather than to a lower growing rate. The contribution of shrinking to long run economic performance is the shrinking rate multiplied by the frequency of shrinking years. All poorer economies had a bigger negative contribution from shrinking than economies with per capita incomes above $\$ 20,000$. This was due to both the higher frequency of shrinking among poorer countries and higher shrinking rates.

Long run economic performance is measured by the net rate of change in per capita incomes in the final column of Table 2. Poorer economies did not have a significantly better long run economic performance than the richest group of countries, which means that there was no systematic catching-up over the period as a whole. Middle income countries increased their per capita incomes at about the same rate as the rich countries, but poor countries increased their per capita incomes substantially more slowly, so that there was unconditional divergence rather than convergence as the poorest countries fell increasingly behind (Pritchett, 1997). This lack of long run convergence is explained mainly by differences between countries in the contribution of shrinking, as rich countries shrank less and in fewer years than poor countries.

The next two sections explore the implications of the post-1950 findings for a longer sweep of economic history, encompassing the transition to modern economic growth in today's rich countries. To do this, we make use of the Maddison Data Base for the nineteenth 
and twentieth centuries, and data on a sample of four European countries for which annual data have recently become available, reaching back to the thirteenth century.

\subsection{Economic performance in the nineteenth and twentieth centuries}

The final version of the Maddison Data Base contains annual data on 14 European countries starting between 1820 and 1870 and 4 New World economies starting in 1870. Annual data for most other economies begin only in the twentieth century, and in many cases after 1950 (Maddison, 2010). Widely accepted revisions to the original Maddison Data Base do not affect these data, but rather focus on the period before 1820 for the 14 European countries and the twentieth century for other economies (Bolt and van Zanden, 2014). Table 3 shows data on the frequency of growing and shrinking for the 18 country sample as a whole, while figures are given for a number of individual countries in Appendix Table A1. The frequency of growing has increased very sharply in the period since 1950 in this group of rich countries in Europe and the New World, or to state it the other way round, there has been a sharp reduction in the frequency of shrinking, from about one third to one eighth.

Table 4 shows the average growth rate in all years, growing years and shrinking years, i.e. long run economic performance, the growing rate and the shrinking rate. Again the data in the text table are provided for the 18 country sample, with data on some individual countries in Appendix Table A2. Since 1950, the growth rate across all years has increased sharply in both Europe and the New World, and this has happened despite the fact that the growing rate (i.e. the growth rate in growing years) has actually fallen substantially almost everywhere. ${ }^{2}$ Long run economic performance improved despite the reduction in the growing

\footnotetext{
${ }^{2}$ The one exception among this sample of 18 countries is Spain, which experienced a faster growing rate post1950 during recovery from the catastrophic effects of the Civil War.
} 
rate because of an even sharper decline in the shrinking rate combined with a reduction in the frequency of shrinking.

It should also be noted from Table 4 that during the period 1910-1950, covering the two World Wars and the Great Depression, the growing rate increased almost everywhere, in many cases substantially so. ${ }^{3}$ However, this did not lead to any significant improvement in long run economic performance because there was an equally sharp increase in the shrinking rate, while the frequency of shrinking also increased slightly. It is natural to associate this increased volatility with the two world wars and the financial crises of the interwar period.

Table 5 shows how the frequency of growing and shrinking interacted with the growing and shrinking rates to produce the contributions of growing and shrinking to long run economic performance, as measured by the average rate of change of per capita income in all years. Data in the text table are presented only for the 18 country sample as a whole, with more detail provided in Appendix Table A3. Again, this makes clear that the improvement in economic performance during 1950-2008 compared with earlier periods can be attributed mainly to a reduction in the contribution of shrinking, since the contribution of growing either stagnated or actually declined slightly in most countries.

\subsection{Economic performance over the very long run}

Recent work in historical national accounting has extended annual estimates of GDP per capita as far back as the thirteenth or fourteenth century for a number of European countries (Broadberry, 2013; Fouquet and Broadberry, 2015). We also analyse this Very Long Run Data Base for Britain, the Netherlands, Italy and Spain (Broadberry et al., 2015; van Zanden

\footnotetext{
${ }^{3}$ Again the exception is Spain, as a result of the Civil War.
} 
and van Leeuwen, 2012; Malanima, 2011; Álvarez Nogal and Prados de la Escosura, 2013). The annual time series are plotted in Figure 1 for Italy and Spain, in Figure 2 for Britain and the Netherlands, with the four countries being considered together in Figure 3. Beginning with the Mediterranean economies in Figure 1, there was a clear alternation of periods of positive and negative trend growth over periods of a decade or more, with growth booms typically followed by growth reversals, leaving little or no progress in the level of per capita incomes over the long run. Per capita GDP therefore fluctuated without long run trend before the mid-nineteenth century. For the cases of Britain and the Netherlands in Figure 2, however, although there were alternating periods of positive and negative growth until the eighteenth century, there was also a clear upward trend over the long run, with the gains following the Black Death being retained, and the growth reversals eventually disappearing with the transition to modern economic growth in the eighteenth century. As periods of negative growth became less frequent and as the rate of shrinking decreased in northwestern Europe, Britain and Holland overtook Italy and Spain, as shown in Figure 3.

It is also useful to quantify the number of significant growing episodes (defined as at least consecutive three years of positive per capita GDP growth) and the number of shrinking episodes (defined as at least three consecutive years of negative per capita GDP growth). The results can be seen in Table 6, assessed over the whole period 1348-1870 and broken down by shorter periods of approximately 50 years. The most striking finding is that for the period as a whole, Britain and the Netherlands overtook Italy and Spain not because of any greater incidence of growing episodes, but rather because of much fewer shrinking episodes. Note further the performance of Britain, the first country to achieve modern economic growth, during its periods of significantly improved per capita GDP performance. Britain experienced fewer growing episodes than all other countries after the Black Death, 1348-1400, fewer 
growing episodes than Italy and Spain after the Civil War 1650-1700, and even after 1800, no more growing episodes than the Netherlands and Spain, and fewer than Italy. Britain's path to modern economic growth and world economic leadership was not obviously the product of more growing episodes.

However, a complete analysis must cover all years rather than just those with at least three consecutive years of growing or shrinking. Tables 7 to 9 show the frequency, rates and contributions of growing and shrinking to long run economic performance over complete periods of roughly fifty years in the Very Long Run Data Base, as in the analysis of the Penn World Table and the Maddison Data Base. The first thing to note from Table 7 is that for all of the economies considered here, the frequency of shrinking was about one third in the nineteenth century, as in Table 3 . For earlier centuries, by contrast, these economies grew and shrank in roughly equal proportions of years. A reduction in shrinking therefore played an important role in the improved long run economic performance of Western Europe. Second, turning to Table 8 , we see that growing and shrinking rates tended to move together, so that high rates of growing were accompanied by high rates of shrinking and low rates of growing were accompanied by low rates of shrinking. Third, the transition to modern economic growth occurred first in Britain during the eighteenth century, where growing and shrinking rates were both low but the growing rate was significantly higher than the shrinking rate and the frequency of growing was greater than the frequency of shrinking. Although there had been an earlier episode between 1450 and 1550 when the growing and shrinking rates were both low and the frequency of growing was greater than the frequency of shrinking, at this time the shrinking rate was higher than the growing rate. Fourth, Table 9 shows the contributions of growing (the frequency of growing multiplied by the growing rate) and shrinking (the frequency of shrinking multiplied by the shrinking rate) to long run economic 
performance (the average rate of change of per capita income in all years). In this table, notice that the rate of economic performance over all years increased from 0.23 per cent in the period $1700-1750$ to 0.79 per cent in the period $1800-1870$ as Britain experienced the first transition to modern economic growth. But this was not caused by an increase in the contribution of growing, which fell from 2.38 per cent in the early period to 1.85 per cent in the later period. Even though the frequency of growing increased over this period from 50 per cent of years to 61 per cent (Table 7), this was offset by a sharp decline in the rate of growing from 4.76 per cent to 3.00 per cent (Table 8 ). On their own, then changes in the rate and frequency of growing would have led to a decline in economic performance. The improved economic performance between $1700-1750$ and $1800-1870$ was thus due to the reduction in the contribution of shrinking from -2.15 to -1.05 per cent, which more than offset the reduction in the contribution of growing (Table 9). This occurred as a result of both the reduction in the frequency of shrinking from 50 to 39 per cent (Table 7) and the reduction in the rate of shrinking from -4.31 to -2.73 per cent (Table 8 ). In terms of a simple decomposition, more than all of the increase in economic performance between the two periods is explained by changes in shrinking rather than growing. ${ }^{4}$

\subsection{A summary of the empirical results}

Before moving on to the explanatory section, it will be useful to summarise the main empirical results, which a framework for understanding long run economic performance needs to be able to explain:

(1) Growing rates and shrinking rates have been high and variable throughout most of history and remain high and variable in less developed economies today

\footnotetext{
${ }^{4}$ Note that the second half of the seventeenth century is not conventionally regarded as a period of modern economic growth because although there was a substantial increase in British per capita GDP, it was accompanied by a small reduction in the population.
} 
(2) Improving long run economic performance has occurred because the frequency and rate of shrinking have both declined, rather than because the growing rate has increased

(3) The rate of growing has typically declined rather than increased as long run economic performance has improved

\section{WHY DO ECONOMIES STOP SHRINKING?}

The previous section has established that the transition to sustained economic growth has historically owed more to a reduction in the rate and frequency of shrinking than to an increase in the rate of growing. Put simply, economic development depends on economies first dampening growth reversals and then stopping shrinking altogether. However, there has been no systematic analysis of shrinking episodes or of the reasons for their disappearance. Rather, shrinking episodes are typically regarded as aberrant anomalies, caused by negative shocks, while their disappearance has gone largely unremarked.

Focusing on the Very Long Run Database, most previous accounts of the Industrial Revolution in Britain seek to explain an increase in the rate of growing rather than a reduction in the rate and frequency of shrinking. As Ashton's [1948: 48] "wave of gadgets swept over England" during the eighteenth century, the average rate of growing during periods of positive growth was actually falling (Table 7). But this still led to improved longrun economic performance because of a decline in the rate and frequency of shrinking. So it is not enough to explain why great inventors discovered coke smelting of iron or the spinning jenny in cotton textiles. We also need to understand why Britain and other parts of Europe stopped shrinking. After all, it has been known for some time that coke smelting of iron was widely used in Northern Song China, seven hundred years before Abraham Darby 
rediscovered it at Coalbrookdale (Hartwell, 1966). And as Allen (2009: 904-907) has pointed out, inventions such as the spinning jenny were so simple in principle that they were almost bound to be discovered once people started looking for them. And yet researchers continue to focus on innovation during periods of positive growth, while the issue of why economies shrink continues to be largely ignored.

So why did growth reversals become dampened after the Black Death and eventually disappear altogether in Britain? Standard growth theory is not much help here, since it assumes away periods of shrinking and focuses only on the long run. In a neoclassical growth model with a production function and emphasis on accumulation and technological progress, it is difficult to see how an economy could shrink by five or ten percent a year for several years. In addressing this question, we follow Maddison (1991: 12) in drawing a distinction between proximate and ultimate elements explaining per capita GDP performance, but focusing on shrinking rather than growing. The main proximate factors considered here are: (1) structural change (2) technological change (3) demographic change and (4) the changing incidence of warfare. Institutional change is also considered as the key ultimate factor behind the reduction in shrinking.

\section{PROXIMATE CAUSES OF THE DECLINE IN SHRINKING}

\subsection{Structural change}

The period 1270-1870 saw a major structural shift of the British economy away from agriculture, which accounted for around 40 per cent of nominal GDP between the late fourteenth century and the end of the sixteenth century, declining to around 30 per cent during the seventeenth and eighteenth centuries, and around 20 per cent by the midnineteenth century (Broadberry et al., 2015: 194). Short-run fluctuations of agricultural 
output were often extremely large, with annual declines of 10 or 20 per cent a frequent occurrence, as weather related shocks led regularly to bad harvests and years of shrinking. As the share of agriculture in overall economic activity declined, therefore, it may be expected that such episodes of shrinking would become less important.

Two observations are appropriate here, however. First, it is clearly more natural to see this as a result rather than a cause of economic development. In line with Engel's Law, the share of income spent on food declines as income increases, so that the industrial and service sectors increasingly come to dominate economic activity. Identifying structural change as a proximate source of the reduction in shrinking does not, therefore, provide any useful policy recommendations.

The second observation concerns the relative importance of structural change and changes in the pattern of growing and shrinking within individual sectors of the economy. We are interested in changes in the balance between growing and shrinking. A reduction in the importance of a particularly volatile sector, such as agriculture, may in fact be expected to affect the growing rate just as much as the shrinking rate, with little effect on long run economic performance. It is useful, therefore, to consider the contributions of growing and shrinking at a sectoral level. Table 10 shows that there was no trend reduction in the frequency of shrinking in agriculture, which remained at around 50 per cent throughout the period 1270-1870. In services, although the frequency of growing was much greater than the frequency of shrinking, there was again no strong trend decline in shrinking. Only in industry was there a clear trend decline in shrinking. Table 11 sets out the average rates of change of output in all years, growing years and shrinking years. In agriculture, output performance in all years improved despite a trend decline in the growing rate as the shrinking rate also 
declined. Services also exhibited an improvement in output performance across all years, but with an increase in both the growing and shrinking rates. Industry is the most interesting sector, with an improvement across all years resulting from a combination of an increase in the growing rate and a decline in the shrinking rate. Table 12 shows how the frequencies and rates of growing and shrinking interacted to determine the contributions of growing and shrinking to long run economic performance, measured as the average rate of change of output in all years. Again, all sectors showed an improved long run economic performance, but industry stands out as the only sector where the contribution of growing increased and the contribution of shrinking declined. In agriculture, the contributions of growing and shrinking both declined, while in services the contributions of growing and shrinking both increased.

The question of the extent to which that the declining share of agriculture might explain the decline in shrinking rates and frequencies in the aggregate economy is addressed directly in Table 13. The table performs a shift-share analysis, comparing the 1270-1348 period with the 1800-1870 period. The first column of Table 13A gives the shares of output in agriculture, industry, and services in 1381, the earliest year for which shares of nominal GDP are available (Broadberry et al., 2015: 194). At this point, agriculture accounted for more than 45 per cent of British GDP. The second column gives the share in 1841, when agriculture's share had fallen to just over 22 per cent. The contributions of growing and shrinking in each sector in each period are taken from Table 12. Table 13B combines the 1381 shares and 1270-1348 contributions with the 1841 shares and 1800-1870 contributions. If the declining share of agriculture is what mattered for the reduction in shrinking at the aggregate level, then comparing the columns that hold contributions constant and allow the shares to shift should show a marked difference in economic performance from the actual performance (shown in the last two rows of the table). Since Table 10 has established that 
agriculture continued to be a highly variable sector of the economy, if the change in contributions holding the shares constant shows a significant change in economic performance, then we can conclude that agriculture was developing too, and that the decline in the importance of shrinking at the aggregate level was not the result of a declining share of agriculture in the economy.

We hold the contributions of growing and shrinking constant for each sector, but vary the sectoral shares, in columns (2) and (4) and in columns (6) and (8) of Table 13B. The effect on aggregate economic performance of shifting the sectoral shares is minimal. In both cases, this leads to only a small change in the net output performance, from 0.16 to 0.19 per cent holding the 1270-1348 contributions constant, and from 1.74 to 2.07 per cent holding the 1800-1870 contributions constant. By contrast, holding the sectoral shares constant and shifting the contributions shows a marked change in net output performance, comparing columns (2) and (6) or columns (4) and (8). In both cases, this leads to a very large change in the net output performance, from 0.16 to 1.74 per cent holding the 1381 shares constant, and from 0.19 to 2.07 per cent holding the 1841 shares constant. In practice, then, the declining share of agriculture explains rather less than might be expected of the patterns of growing and

shrinking that are observed in the data. Conversely, developments within each of the individual sectors, including agriculture, were of rather more importance.

\subsection{Technological change}

In theory, shrinking could disappear as the economy moves from technological stagnation to technological progress. In a world with no technological progress, an upturn must lead to positive per capita GDP growth, while a downturn must lead to negative growth i.e. shrinking. The emergence of trend technological progress for the first time could therefore 
lead to the elimination of shrinking, at least in theory. Imagine that the entire distribution of growing and shrinking episodes shifts a fixed amount towards growing. Shrinking rates and frequencies would both decline. Growing rates and frequencies should both increase, and we have already seen that is inconsistent with the historical or contemporary data on economic performance. But as a kind of robustness check, we can ask whether, in practice, the scale of trend growth in total factor productivity (TFP) at the time of the transition to modern economic was large enough to explain the declining shrinking rates and frequencies we observe.

The main constraint in measuring TFP growth in the past is the lack of reliable data on the capital stock. For Britain, however, Feinstein's (1988) estimates back to 1760 have been produced using the perpetual inventory method, ensuring consistency between the stock of capital and the flows of investment. The augmented Solow growth accounting estimates of Crafts (1995) in Table 14 derive TFP growth taking into account the growth of human capital as well as raw labour and physical capital. As annual output growth accelerated from 0.60 per cent during 1760-1780 to reach a peak of 2.40 per cent during 1831-1873, TFP growth increased only from 0.05 to 0.35 per cent. TFP growth therefore accounted for just one-sixth of the increase in output growth, with five-sixths of the increase being accounted for by faster growth of factor inputs.

Estimates of TFP growth for Holland are provided by van Zanden and van Leeuwen (2012), covering the period 1540-1800 and including human capital as well as labour and capital inputs. In Table 15, Dutch TFP is estimated using the same weights as those used by Crafts and Harley (1992) for Britain (0.4 for capital, 0.35 for labour and 0.25 for human capital). These estimates differ only very slightly from those of van Zanden and van 
Leeuwen, who also include land as a fourth factor input. The period of fastest TFP growth was 1540-1620, during the Dutch Golden Age, at 0.64\% per annum. This was higher than at any other time in Holland during the seventeenth and eighteenth centuries, or in Britain during the eighteenth and nineteenth centuries, but was still relatively small compared with the average growing and shrinking rates for the Netherlands in Table 8. Furthermore, this period of positive TFP growth was followed by a period of strongly negative TFP growth between 1620 and1665, and barely positive TFP growth thereafter, so there was no trend increase in TFP over the period 1540-1800 as a whole. The Dutch example thus serves as a reminder that growth reversals can occur in TFP as well as GDP per capita, and that the transition to modern economic growth requires an end to TFP growth reversals as well as GDP per capita growth reversals.

\subsection{Demographic change}

The Malthusian approach explains long-run stagnation of GDP per capita in the pre-industrial world with shorter episodes of growing and shrinking through demographic factors (Malthus, 1798; Clark, 2007). Malthus assumed feedback from income per capita to fertility (the preventive check) and mortality (the positive check) together with diminishing returns to land (the resource constraint). Short-run growing of per capita income occurs in response to anything which reduces population (an increase in mortality or a decline in fertility) or increases the availability of land. Short-run shrinking of per capita income occurs in response to a decline in mortality, an increase in fertility or a reduction in the availability of land. In the Malthusian approach, however, any gain to GDP per capita will only be temporary because of the feedback from living standards to fertility and mortality. 
As noted earlier, the growth in living standards in Italy after the Black Death of the mid-fourteenth century, and its subsequent reversal after the return to population growth from the mid-fifteenth century, can be understood in the light of the Malthusian model. However, other countries do not fit into this approach at all well. Most obviously, Britain and the Netherlands were able to break free during the early modern period from the Malthusian constraints that held Italy on a path of long-run stagnation, despite similar demographic trends. As population returned to its pre-Black Death level in Britain and Holland during the sixteenth and seventeenth centuries, Holland enjoyed its Golden Age of economic growth, while British living standards remained on a plateau rather than declining.

For England, excellent demographic data exist for the period since 1541, as the result of a major research project by Wrigley and Schofield (1981), and can be considered alongside the GDP per capita data examined in section 2 of this paper. Figure 4 provides a graph of annual data on the crude birth rate and the crude death rate per 1,000 population. It is immediately clear that England's breaking out of the Malthusian trap in the eighteenth century was not caused by a reduction in fertility or an increase in mortality. Indeed, there was a population explosion after 1750 as fertility increased substantially while mortality declined (Wrigley and Schofield, 1981: 314-315). Furthermore, when the fertility transition did begin in England with the decline in the crude birth rate from the 1870 s, there was a decline in economic performance. The fertility decline from the 1870 s can be seen clearly for England in Figure 4, and applies also to the rest of Britain (Tranter, 1996: 86). The decline in economic performance shows up in the GDP per capita growth rate for the UK in Table A2, and is conventionally referred to as the late Victorian climacteric (Matthews et al., 1982). 
Spain provides another interesting example of an economy behaving in a nonMalthusian way after the Black Death. In contrast to Italy, the Netherlands and Britain, Spain did not experience even a temporary increase in per capita incomes after the Black Death. Álvarez-Nogal and Prados de la Escosura (2013) explain this by the high land-to-labour ratio in a frontier economy during the Reconquest. Instead of reducing pressure on scarce land resources, Spanish population decline destroyed commercial networks and further isolated an already scarce population, reducing specialisation and the division of labour. Thus Spain did not share in the general west European increase in per capita incomes after the Black Death. This serves as a useful reminder that the mechanical operation of demographic forces highlighted in the Malthusian approach can be offset and dominated by the forces of coordination emphasised in the Smithian approach. Explaining the changing relationship between population, output and per capita output has proved difficult enough in unified growth theory, even abstracting from the issue of shrinking (Galor and Weil, 2000; Galor, 2005).

\subsection{Changing incidence of warfare}

The outbreak of war and the return to peace can be seen as shocks to economic activity, with effects on growing and shrinking both directly, through disruption to business, and indirectly through Malthusian effects on demography. An increase or a reduction in the incidence of warfare could therefore in principle have had significant effects on the frequency and rate of shrinking. A case for the direct effects could be made, for example, when comparing the period 1910-1950 in Table 5 with the prewar period 1870-1910 or the postwar period, 19502008. The outbreak of World War I clearly created considerable difficulties for trans-national businesses, making it impossible for normal commercial relationships between Britain and Germany, for example, while the return of peace in 1918 allowed for a period of recovery in 
trans-national business, disrupted once again by the outbreak of World War II (Reader, 1970: 249-314; 1975: 251-296; Broadberry, 1997: 210-291). The higher rates of shrinking and growing in the period 1910-1950 compared with both the pre-1910 and post-1950 periods, but without improved long run economic performance, can be understood in this light. However, Malthusian effects on living standards during and after the two world wars are much less apparent. Higher mortality and reduced fertility during the wars does not seem to have been associated with prosperity, while postwar baby booms do not seem to have led to slower growth of GDP per capita, particularly after World War II (Urlanis, 1971: 248-312).

The role of war and peace in the transition to modern economic growth has attracted the attention of a number of writers in recent years. Building on the work of Jones (1981) and Tilly (1990), Hoffman (2015) argues that the fragmentation of Europe into a large number of warring nations led to the development of states with high per capita revenues that were spent largely on warfare, and stimulated the development of technologies which had useful spillovers into civilian economic activity. Hoffman's stress on the institutions of governance and technological progress are in stark contrast to Voigtländer and Voth's (2013a) emphasis on the Malthusian aspects of warfare. Voigtländer and Voth (2013b) see a "First Divergence" between 1350 and 1700 as Europe laid the foundations of the "Great Divergence" after 1700. War, together with plague and urbanisation, is seen as good for development as it raised mortality, hence lowering population growth and allowing an increase in per capita incomes. To this effect, which they see as the "gift of Mars", Voigtländer and Voth (2013c) add the "invention of fertility restriction" after the Black Death to consolidate the gift of Mars by keeping fertility low. 
From our perspective, both the Malthusian and the institutional/technological versions of the "war as the driver of economic progress" thesis suffer from a failure to pay sufficient attention to the effects on shrinking as well as growing. Historically, the main effect of warfare has been to raise both the frequency and rate of shrinking during the war, offset by an increase in the rate of growing during the postwar recovery. The net effect of this on long run economic performance has been relatively small, even during the total wars of the twentieth century (Broadberry and Harrison, 2008). In explaining the transition to modern economic growth, what we are looking for is something that led to a reduction in the rate and frequency of shrinking, and wars had the opposite effect.

\section{ULTIMATE CAUSES OF THE DECLINE IN SHRINKING}

This section adopts a Smithian approach to the explanation of shrinking and its dampening during the process of economic development. Smithian growth occurs with an increase in the extent of the market and the greater division of labour, while Smithian shrinking occurs with a reduction in the extent of the market (Smith, 1776). The basic idea builds on a tradition associated with the work of Douglass North, who emphasised the importance of institutional change in bringing about modern economic growth in a series of papers and books reaching back as far as 1961 (North 1961, see Wallis 2016), clearly articulated in North and Weingast (1989) and North (1990). However, in common with most other economic historians, North in his early work emphasised the need to increase economic growing, without considering the possibility of improved economic performance through reduced shrinking. This shift of emphasis appeared for the first time during North's collaboration with John Wallis and Barry Weingast in North et al. (NWW, 2009).

\subsection{Institutional change}


Most early work on institutions, including North up through 1990, assumed that rules were meant to apply equally to everyone in principle, but in practice they often did not. Credible commitment to enforce the rules was lacking, and how to create credible commitment on the part of the government was a key concern of North and Weingast (1989) and North (1990). NWW raised a different set of issues, with important implications for the nature of rules. In a world where violence was endemic, powerful individuals and organizations had an incentive to create social order. To do so credibly, however, meant that powerful actors had to believe that the other powerful actors would honour commitments not to use violence. NWW developed the idea of the "natural state" to explain how such arrangements could work. Powerful actors recognized each other's ability to control resources in return for promises not to fight. Because the resources of the actors would be less valuable if fighting occurred, their arrangements created conditions under which powerful organizations could find it in their interest to honour their commitments not to use violence, but only within a narrow range of conditions. NWW call this the logic of the natural state.

Critically, the rules that emerge from the agreements between powerful organizations explicitly could not treat everyone the same. The rules had to recognize the privileges of powerful elites, often on an individual basis. Rules that treat individuals differently are an important source of the rents that make intra-elite agreements credible. As long as the rents produced by elite agreements are reduced by violence, then elites have a stronger incentive to limit violence and honour their agreement. The rules that emerge in a natural state are "identity rules:" rules whose form and enforcement differ according to the organizational identity of the individuals to whom the rule applies. ${ }^{5}$ The logic of the natural state produces a

\footnotetext{
${ }^{5}$ North, Wallis, and Weingast do not use the term identity rules in their book. For the development of the idea of identity rules see Wallis (2011), where he calls them anonymous rules.
} 
coalition of powerful organizations that limit violence, but the rules governing the interaction of those organizations, and elite individuals generally, are identity rules.

A system of identity rules creates two kinds of problems, one for powerful elites and the other for the entire society. Because the rules and enforcement favour them, powerful elites face a paradox of privilege: the more powerful the elite, the less able he is to bind himself by rules that can be enforced by the courts. The king, as the saying used to go, is above the law. The paradox of privilege is compounded by the uncertainty of elite identity, the second problem. The power of specific elites is tied to their organizations, which are often factions, parties, and alliances rather than legally recognized entities (that comes later), and the relative power of organizations rises and falls unpredictably over time. Sometimes the relative power of organizations, and thus elite identity, can change quickly and unexpectedly. When that happens, how identity rules will be applied may not change in principle, but since the identities of elite individuals and organizations have changed, how the rules apply to specific individuals changes. This creates significant complications for the idea of credible commitment as an organizing theme of institutional analysis. Governments can be credibly committed to enforcing identity rules, but the identities themselves are uncertain and changeable.

The transition from natural states to open access orders depends on the ability of societies to create and enforce some impersonal rules: rules that treat everyone the same. The "open" in open access refers to the ability to form organizations, which is limited in natural states. Identity rules and enforcement are an integral part of the limits that create the rents that provide credible incentives underlying the social order (to put all the links together in one sentence). The transition from an identity rule regime to an impersonal rule regime 
involves much more than just a change in the enforcement of rules, it requires a shift in the pattern of social dynamics, which we will not consider here.

What matters for the rate and frequency of shrinking are the two problems with identity rules. First, the paradox of privilege means that some elite relationships that could be credible if an elite relationship could draw on the unbiased enforcement of a contractual agreement, will not be feasible. Specifically, agreements that require the more powerful elite to be bound by the rules will not be feasible. In Smithian terms, since elite organizations stand at the nexus of commercial, economic, political, and social networks, the degree of coordination within a society through those networks will determine the degree of specialization and division of labour. The paradox of privilege will limit the range of supportable elite arrangements, and so the extent of the market. This will appear as a problem of scale, and so many of the new growth theory ideas that extend Smith's insights apply to this long term problem.

But even more important in terms of shrinking is the problem of shifting elite identities. Looking forward in time, elite relationships that would be credible if elite identities, and therefore elite rule enforcement, remain stable over time, may not be credible if elite identities are uncertain, or become more uncertain, going forward in time. Looking backward in time, when a shock occurs and elite identities change, relationships that were sustainable suddenly become problematic. Elite relationships break down, division of labour and specialization are reduced and the economy shrinks. A shock may have both an immediate effect on output, and then an ongoing effect through elite relationships. ${ }^{6}$ The long run Smithian forces mean that identity rule societies have a lower level of economic

\footnotetext{
${ }^{6}$ Rodrik's (1999) paper "Where did all the growth go?" is a neat and clean example of this phenomenon, using the 1973 oil shock as an identification strategy.
} 
performance for long run structural reasons, and the short run Smithian forces mean that identity rule societies are more subject to shrinking, and thus lower levels of economic performance over the long run. Both factors are at work.

Broadberry and Wallis (2016) develop this argument to show how a reduction in shrinking occurs with institutional change during economic development, as an economy moves from operating with a system of identity rules to a system of impersonal rules. We see this as the major change behind the transition to modern economic growth in today's developed economies as well as in today's newly developing countries. In very simple terms, elites can be ordered in terms of their power, which is determined by their ability to control resources. Since the ability to control resources changes over time, elite orderings also change, both in a prospective and retrospective way. Changing elite identity does not matter for the enforcement of impersonal rules, but is crucial for the enforcement of identity rules.

Two important results follow from this. First, elite relationships which would be viable in an impersonal rule society may not be viable in an identity rule society, simply because there is no mechanism for the most powerful elites to credibly commit to an agreement that could be enforced in the courts. Second, changes in elite ordering can bring about shrinking episodes in identity rule societies, but not in impersonal rule societies. In identity rule societies, business relations which were viable in the old ordering may cease to be viable in the new ordering, and it takes time for new relationships to develop, since they depend on establishing credible commitment. Long-run development, where episodes of growth are not routinely followed by episodes of shrinking, therefore requires a transition from a world of identity rules to a world of impersonal rules. 


\subsection{Interaction between proximate and ultimate factors}

We have identified institutional change as the key ultimate factor behind the reduction in shrinking, leading to the transition to modern economic growth. We end by considering how institutional change can operate through changes in the proximate factors. As Maddison (1988) notes, the interactions between proximate and ultimate factors can be complex, but a number of consequences can be seen to follow from the institutional changes leading to an impersonal rule society, where a change in the ordering of elites does not interfere with the set of feasible contracts. First, diversification becomes easier in a world where everyone is treated the same, and the need to hang on to land to ensure access to food during periods of crisis becomes less important, facilitating a move away from dependence on agriculture (Solar, 1995). Second, these same forces encourage experimentation amongst a wider group of people and thus an increase in the rate of technological progress (Kahn, 2005). Third, the increase in technological progress can be expected to bring about a demographic transition via the need for human capital, as in unified growth theory (Galor, 2005). Fourth, the perceived fairness of a legal system where rules are enforced impersonally should lead to a more peaceful environment (Pinker, 2011).

\section{CONCLUSIONS}

Work by development economists during the 1990s highlighted the importance of episodes of shrinking for keeping economies poor in the contemporary world. Easterly et al. (1993) used data from the post-1950 period to highlight that the main difference between poor and rich countries was not that the poor countries grew more slowly than the rich countries when they were growing, but rather that they grew in less years, and indeed experienced many years of very rapid negative growth, or "growth reversals". Viewed in this light, the problem of development becomes one of reducing the variability of short-run growth rates, rather than 
increasing short-run growth rates. Pritchett (2000) uses a topographical analogy to describe the difference between those countries that have made the transition to modern economic growth and those that have not. Modern economic growth is a "continuous hill" and getting there is the final stage of a dynamic process, which involves dampening growth reversals, thus avoiding "mountains", but also "plains" and "plateaus". This approach can be applied equally to the pre-World War II period, now that annual data are available back to the nineteenth century for a sample of 18 countries and back to the medieval period for a sample of 4 countries. Britain, the first country to achieve modern economic growth, during the eighteenth century, began the process of dampening growth reversals as early as the medieval period, following the gains to per capita income after the demographic shock of the Black Death.

How did the successfully developing economies dampen and ultimately eliminate episodes of shrinking? Here we distinguish between proximate and ultimate factors, with structural change, technological change, demographic change and the changing incidence of warfare as the main proximate factors. First, agriculture, with its exposure to shrinking through weather shocks and climate change, has typically declined in importance during the process of economic development. However, this is better seen as a result rather than a cause of development, and it is important to consider the effects on both the growing rate and the shrinking rate, since it is the difference between the two that determines the impact on long run economic performance. Second, a movement from long run technological stagnation to trend growth of TFP can turn downturns from years of negative growth to slower positive growth, although the increase in TFP growth, during the early stages of economic development has been dwarfed by the decline in the rate of shrinking. Third, a reduction in population growth can bring about reduced shrinking, although in many cases, the transition 
to modern economic growth was accompanied by an increase in the rate of population growth, with a demographic transition occurring only later. Fourth, a reduction in the incidence of warfare can similarly bring about reduced shrinking, although the transition to modern economic growth has often occurred during a period of intensification rather than diminution of warfare. Turning to ultimate factors, we show how institutional change can bring about the transition to modern economic growth, as society makes the transition from a system of identity rules to a system of impersonal rules. This can operate through changes in the proximate factors, as the economy diversifies away from agriculture and experiences an increase in technological progress, a demographic transition and a more peaceful environment. 
Table 1: Penn World Table 8.0: Growing and shrinking, 1950-2011

\begin{tabular}{lrrrr}
\hline $\begin{array}{l}\text { Per capita income } \\
\text { in } 2000\end{array}$ & $\begin{array}{r}\text { Frequency } \\
\text { of growing } \\
\text { years }\end{array}$ & $\begin{array}{r}\text { Average } \\
\text { growing } \\
\text { rate }\end{array}$ & $\begin{array}{r}\text { Frequency } \\
\text { of shrinking } \\
\text { years }\end{array}$ & $\begin{array}{r}\text { Average } \\
\text { shrinking } \\
\text { rate }\end{array}$ \\
\hline Over $\$ 20,000$ & & & & \\
$\$ 10,000$ to $\$ 20,000$ & 0.84 & 3.85 & 0.16 & -2.22 \\
$\$ 5,000$ to $\$ 10,000$ & 0.80 & 4.85 & 0.20 & -4.25 \\
$\$ 2,000$ to $\$ 5,000$ & 0.78 & 5.15 & 0.22 & -4.89 \\
Less than $\$ 2,000$ & 0.72 & 4.72 & 0.28 & -4.29 \\
\hline
\end{tabular}

Sources and notes: Penn World Table 8.0, http://www.rug.nl/research/ggdc/data/pwt/pwt-8.0. The "Real GDP per capita (Constant Prices: Chain series)" and their calculated annual growth rates for that series "Growth rate of Real GDP per capita (Constant Prices: Chain series)" were used to construct this table. Countries were first sorted into income categories based on their income in 2000, measured in 2005 dollars. Average annual positive and negative growth rates are the simple arithmetic average for all of the years and all of the countries in the income category without any weighting. The Penn World Table includes information on 167 countries. The sample runs from 1950 to 2011, although information is not available for every country in every year. Countries are included only where information is available at least as far back as 1970, resulting in a sample of 141 countries.

Table 2: Penn World Table 8.0: The contribution of growing and shrinking to the economic performance of countries by income categories, 1950-2011

\begin{tabular}{lrrr}
\hline $\begin{array}{l}\text { Per capita income } \\
\text { in } 2000\end{array}$ & $\begin{array}{r}\text { Contribution of } \\
\text { growing } \\
\text { (frequency*rate) }\end{array}$ & $\begin{array}{r}\text { Contribution of } \\
\text { shrinking } \\
\text { (frequency*rate) }\end{array}$ & $\begin{array}{r}\text { Net rate of } \\
\text { change of per } \\
\text { capita income }\end{array}$ \\
\hline Over $\$ 20,000$ & & & \\
$\$ 10,000$ to $\$ 20,000$ & 3.23 & -0.39 & 2.84 \\
$\$ 5,000$ to $\$ 10,000$ & 3.82 & -0.88 & 2.94 \\
$\$ 2,000$ to $\$ 5,000$ & 4.00 & -1.13 & 2.87 \\
Less than $\$ 2,000$ & 3.30 & -1.27 & 2.03 \\
\hline
\end{tabular}

Source: Penn World Table 8.0, http://www.rug.nl/research/ggdc/data/pwt/pwt-8.0. 
Table 3: Frequency of growing and shrinking, 18 European and New World countries, 1820-2008

$1820-1870 \quad 1870-1910 \quad 1910-1950 \quad 1950-2008$

$\begin{array}{lllll}\text { Growing } & 0.66 & 0.67 & 0.65 & 0.88 \\ \text { Shrinking } & 0.34 & 0.33 & 0.35 & 0.12\end{array}$

Source: Derived from Maddison (2010).

Table 4: Average rate of change of per capita income in all years, growing years and shrinking years, 18 European and New World countries, 1820-2008

\begin{tabular}{lrrrr}
\hline & $1820-1870$ & $1870-1910$ & $1910-1950$ & $1950-2008$ \\
\hline All years & 1.40 & 1.31 & 1.23 & 2.55 \\
Growing & 3.88 & 3.16 & 5.20 & 3.06 \\
Shrinking & -3.04 & -2.30 & -6.10 & -1.23 \\
\hline
\end{tabular}

Source: Derived from Maddison (2010).

Table 5: Contributions of growing (frequency*rate) and shrinking (frequency*rate) to long run economic performance (average rate of change of per capita income in all years), 18 European and New World countries, 1820-2008

\begin{tabular}{lrrrr}
\hline & $1820-1870$ & $1870-1910$ & $1910-1950$ & $1950-2008$ \\
\hline All years & 1.40 & 1.31 & 1.23 & 2.55 \\
Growing & 2.47 & 2.10 & 3.33 & 2.72 \\
Shrinking & -1.08 & -0.79 & -2.09 & -0.16 \\
\hline
\end{tabular}

Source: Derived from Maddison (2010). 
FIGURE 1: Real GDP per capita in Italy and Spain 1270-1850 (1990 international dollars, log scale)

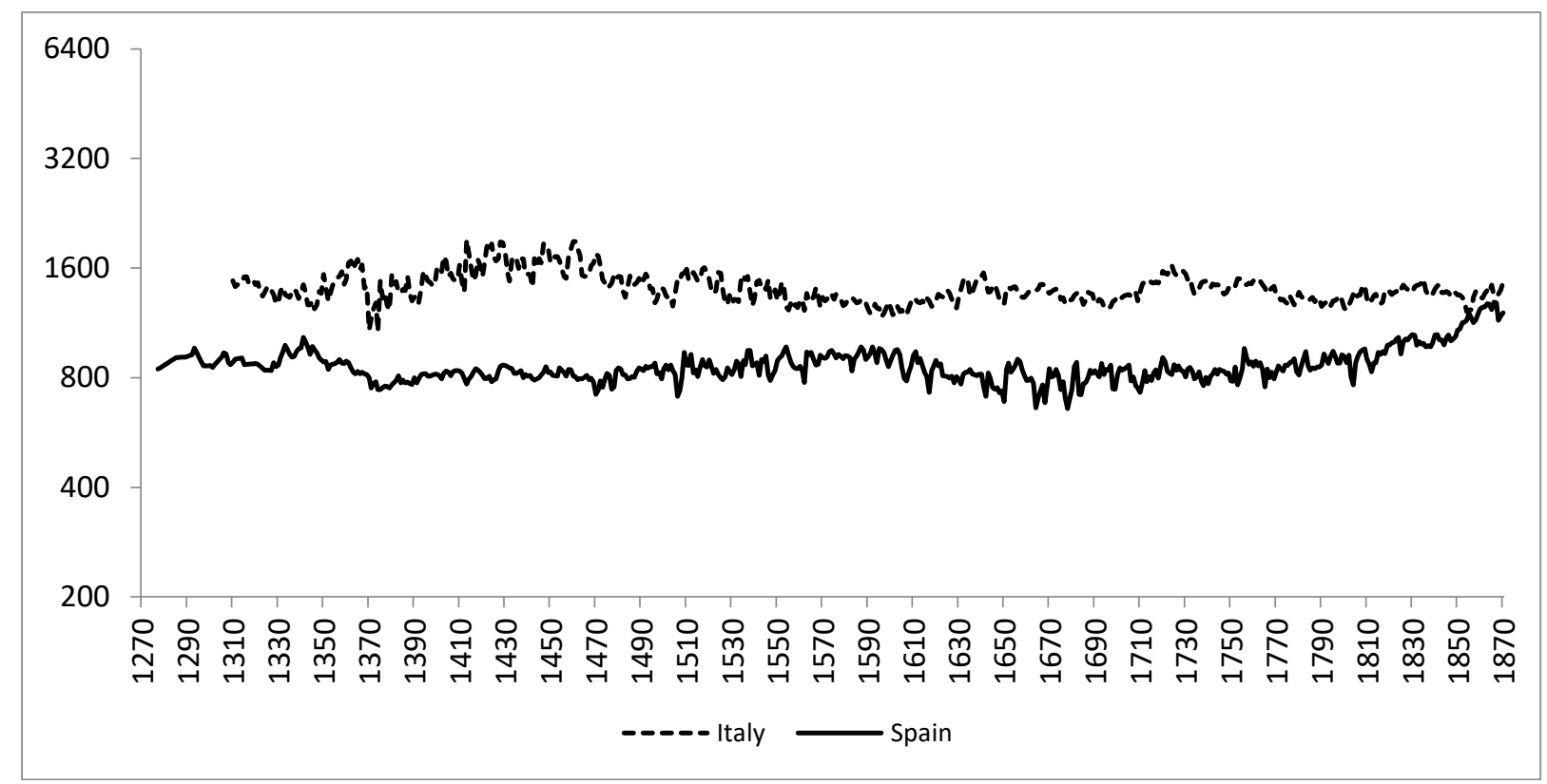

Sources: Malanima (2011); Álvarez-Nogal and Prados de la Escosura (2012).

FIGURE 2: Real GDP per capita in Britain and the Netherlands, 1270-1870 (1990 international dollars, log scale)

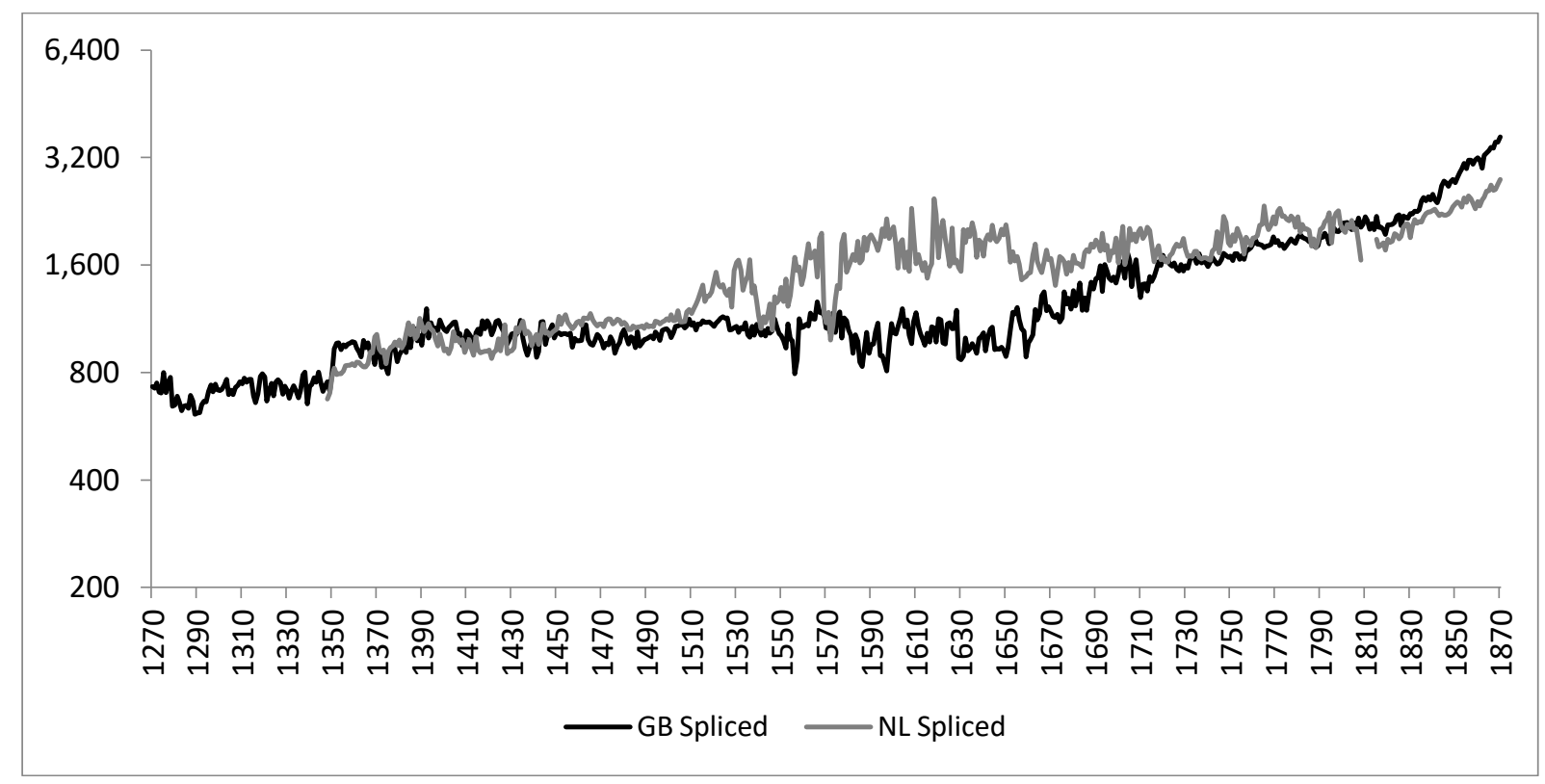

Sources: Broadberry et al. (2015); van Zanden and van Leeuwen (2012). 
FIGURE 3: Real GDP per capita in Britain, the Netherlands, Italy and Spain 1270-1870 (1990 international dollars, log scale)

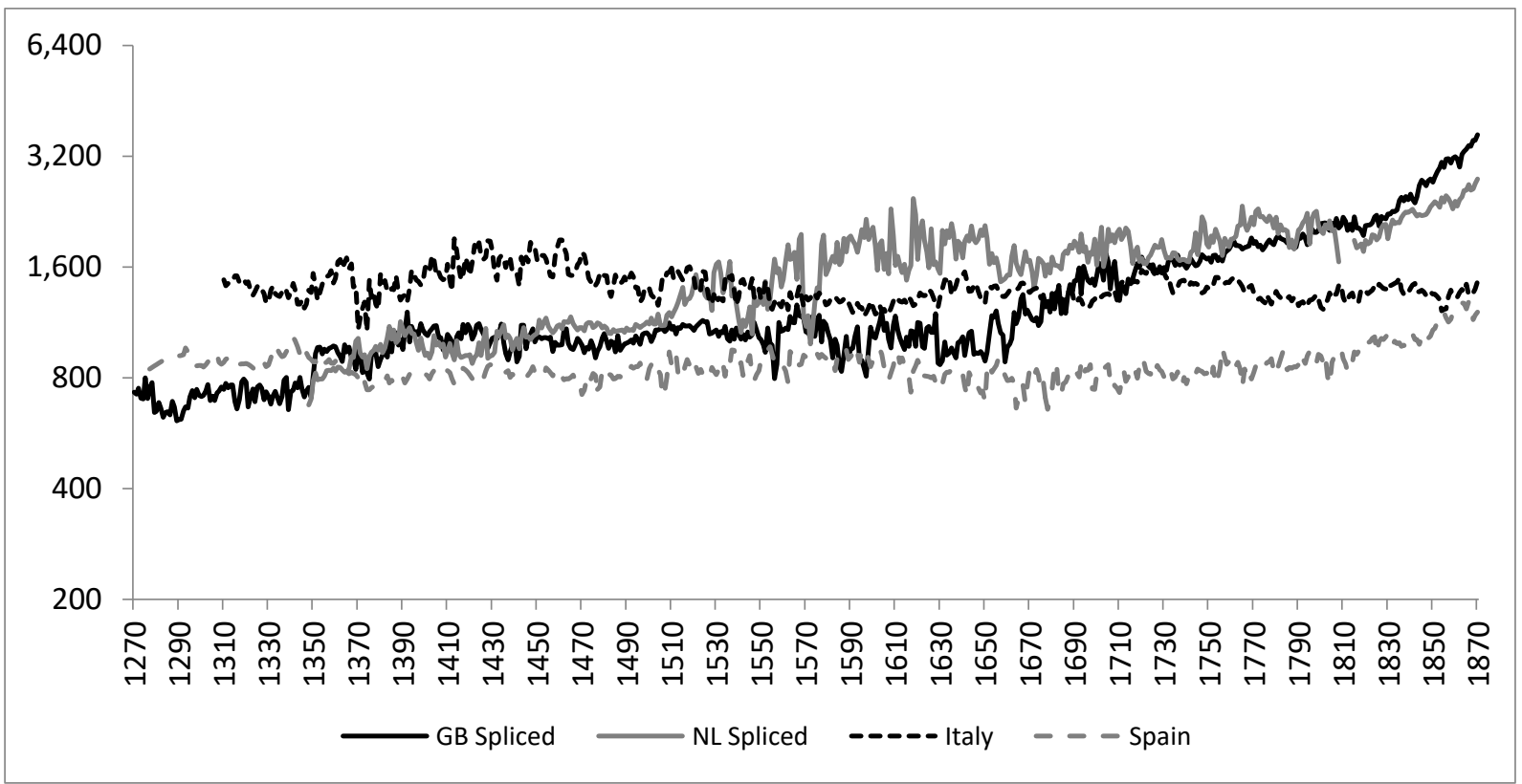

Sources: Figures 1 and 2. 
TABLE 6: Significant growing episodes $(\geq 3$ consecutive years of positive per capita GDP growth) and shrinking episodes ( $\geq 3$ consecutive years of negative per capita GDP growth)

A. Number of growing episodes per period

\begin{tabular}{rrrrr}
\hline & Great Britain & Netherlands & Italy & Spain \\
\hline $1348-1400$ & 3 & 5 & 4 & 5 \\
$1400-1450$ & 6 & 4 & 0 & 3 \\
$1450-1500$ & 4 & 3 & 3 & 2 \\
$1500-1550$ & 3 & 5 & 3 & 2 \\
$1550-1600$ & 1 & 4 & 4 & 4 \\
$1600-1650$ & 3 & 1 & 5 & 3 \\
$1650-1700$ & 3 & 1 & 5 & 4 \\
$1700-1750$ & 2 & 2 & 4 & 2 \\
$1750-1800$ & 4 & 3 & 4 & 3 \\
$1800-1870$ & 6 & 6 & 8 & 6 \\
\hline $1348-1870$ & 35 & 34 & 40 & 34 \\
\hline
\end{tabular}

B. Number of shrinking episodes per period

\begin{tabular}{rrrrr}
\hline & Great Britain & Netherlands & Italy & Spain \\
\hline $1348-1400$ & 2 & 2 & 1 & 2 \\
$1400-1450$ & 3 & 0 & 2 & 3 \\
$1450-1500$ & 2 & 3 & 5 & 4 \\
$1500-1550$ & 1 & 1 & 2 & 2 \\
$1550-1600$ & 4 & 1 & 4 & 3 \\
$1600-1650$ & 2 & 1 & 3 & 5 \\
$1650-1700$ & 3 & 3 & 4 & 1 \\
$1700-1750$ & 0 & 3 & 1 & 4 \\
$1750-1800$ & 2 & 2 & 4 & 0 \\
$1800-1870$ & 0 & 1 & 3 & 1 \\
\hline $1348-1870$ & 19 & 17 & 29 & 25 \\
\hline
\end{tabular}

Sources: Derived from Broadberry et al. (2015); van Zanden and van Leeuwen (2012); Malanima (2011); Álvarez-Nogal and Prados de la Escosura (2013). 
Table 7: Very Long Run Data Base: The frequency of growing and shrinking of GDP per capita

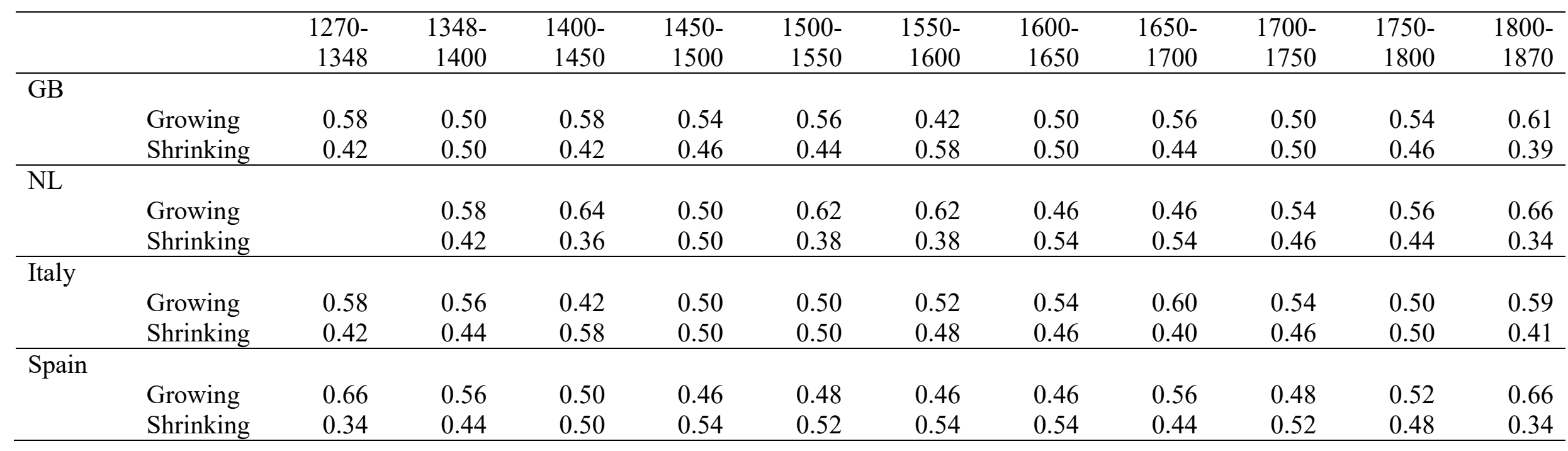

Sources: Derived from Broadberry et al. (2015); van Zanden and van Leeuwen (2012); Malanima (2011); Álvarez-Nogal and Prados de la Escosura (2013). 
Table 8: Very Long Run Data Base: Average rate of change of per capita income in all years, growing years and shrinking years

\begin{tabular}{|c|c|c|c|c|c|c|c|c|c|c|c|c|}
\hline & & $\begin{array}{r}1270- \\
1348\end{array}$ & $\begin{array}{r}1348- \\
1400\end{array}$ & $\begin{array}{r}1400- \\
1450\end{array}$ & $\begin{array}{r}1450- \\
1500\end{array}$ & $\begin{array}{r}1500- \\
1550 \\
\end{array}$ & $\begin{array}{r}1550- \\
1600 \\
\end{array}$ & $\begin{array}{r}1600- \\
1650 \\
\end{array}$ & $\begin{array}{r}1650- \\
1700 \\
\end{array}$ & $\begin{array}{r}1700- \\
1750 \\
\end{array}$ & $\begin{array}{r}1750- \\
1800 \\
\end{array}$ & $\begin{array}{r}1800- \\
1870 \\
\end{array}$ \\
\hline \multirow[t]{3}{*}{ GB } & All years & 0.04 & 0.64 & -0.04 & 0.02 & -0.05 & 0.04 & -0.31 & 1.07 & 0.23 & 0.43 & 0.79 \\
\hline & Growing & 4.29 & 6.45 & 4.15 & 3.02 & 2.48 & 9.31 & 5.92 & 7.23 & 4.76 & 2.47 & 3.00 \\
\hline & Shrinking & -5.76 & -5.16 & -5.83 & -3.51 & -3.28 & -6.66 & -6.54 & -6.77 & -4.31 & -1.98 & -2.73 \\
\hline \multirow[t]{3}{*}{ NL } & All years & & 0.60 & 0.28 & 0.12 & 0.42 & 0.78 & 0.02 & -0.49 & 0.22 & 0.21 & 0.46 \\
\hline & Growing & & 3.96 & 3.80 & 2.09 & 5.39 & 8.65 & 11.93 & 5.87 & 5.27 & 4.77 & 2.49 \\
\hline & Shrinking & & -3.98 & -5.99 & -1.86 & -7.68 & -12.05 & -10.13 & -5.91 & -5.70 & -5.61 & -3.43 \\
\hline \multirow[t]{3}{*}{ Italy } & All years & -0.18 & 0.28 & 0.08 & -0.35 & -0.14 & -0.10 & 0.05 & 0.11 & 0.08 & -0.23 & 0.23 \\
\hline & Growing & 2.44 & 6.09 & 7.77 & 3.39 & 4.29 & 3.05 & 2.68 & 1.70 & 1.90 & 1.76 & 2.23 \\
\hline & Shrinking & -3.78 & -7.05 & -5.43 & -4.08 & -4.56 & -3.51 & -3.04 & -2.28 & -2.06 & -2.23 & -2.60 \\
\hline \multirow[t]{3}{*}{ Spain } & All years & 0.10 & -0.20 & 0.03 & 0.03 & 0.10 & 0.00 & -0.52 & 0.34 & -0.08 & 0.31 & 0.39 \\
\hline & Growing & 1.35 & 1.30 & 1.72 & 2.80 & 5.14 & 3.58 & 3.55 & 5.40 & 3.52 & 4.18 & 2.65 \\
\hline & Shrinking & -2.35 & -2.09 & -1.66 & -2.32 & -4.54 & -3.04 & -3.99 & -6.11 & -3.40 & -3.87 & -3.93 \\
\hline
\end{tabular}

Sources: Derived from Broadberry et al. (2015); van Zanden and van Leeuwen (2012); Malanima (2011); Álvarez-Nogal and Prados de la Escosura (2013). 
Table 9: Very Long Run Data Base: Contributions of growing (frequency*rate) and shrinking (frequency* rate) to long run economic performance (average rate of change of per capita income in all years)

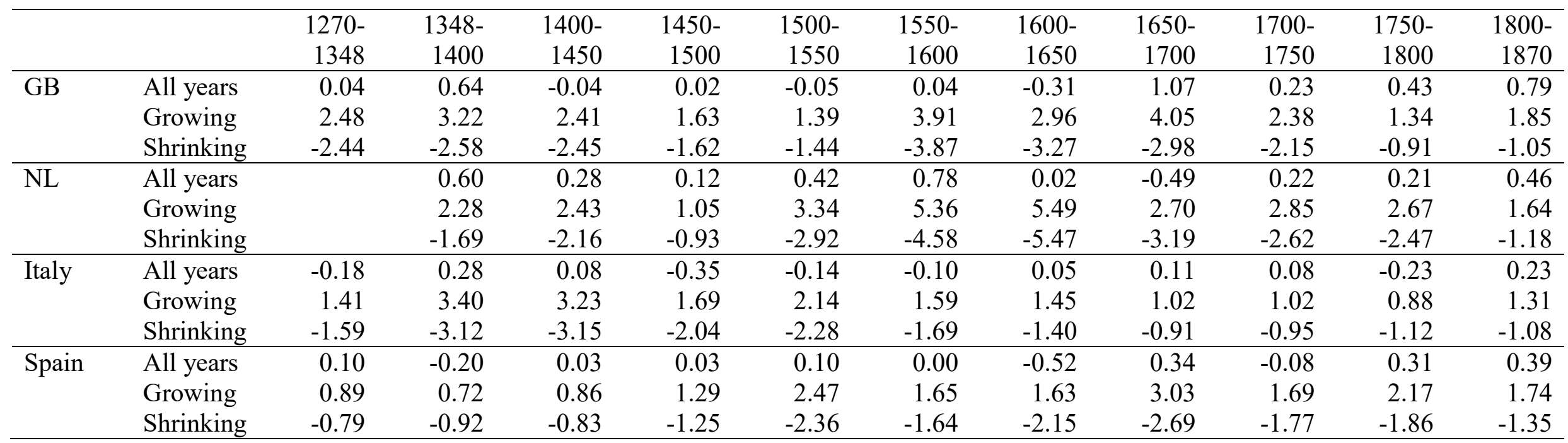

Sources: Derived from Broadberry et al. (2015); van Zanden and van Leeuwen (2012); Malanima (2011); Álvarez-Nogal and Prados de la Escosura (2013). 
Table 10: British Sectoral Data Base: The frequency of growing and shrinking

\begin{tabular}{|c|c|c|c|c|c|c|c|c|c|c|c|c|}
\hline & & $\begin{array}{r}1270- \\
1348\end{array}$ & $\begin{array}{r}1348- \\
1400\end{array}$ & $\begin{array}{r}1400- \\
1450\end{array}$ & $\begin{array}{r}1450- \\
1500\end{array}$ & $\begin{array}{r}1500- \\
1550\end{array}$ & $\begin{array}{r}1550- \\
1600 \\
\end{array}$ & $\begin{array}{r}1600- \\
1650 \\
\end{array}$ & $\begin{array}{r}1650- \\
1700\end{array}$ & $\begin{array}{r}1700- \\
1750\end{array}$ & $\begin{array}{r}1750- \\
1800\end{array}$ & $\begin{array}{r}1800- \\
1870 \\
\end{array}$ \\
\hline & Growing & 0.53 & 0.50 & 0.56 & 0.54 & 0.50 & 0.48 & 0.52 & 0.52 & 0.46 & 0.54 & 0.51 \\
\hline \multicolumn{13}{|l|}{ Industry } \\
\hline & Growing & 0.56 & 0.50 & 0.48 & 0.60 & 0.78 & 0.48 & 0.62 & 0.56 & 0.56 & 0.64 & 0.71 \\
\hline & Shrinking & 0.44 & 0.50 & 0.52 & 0.40 & 0.22 & 0.52 & 0.38 & 0.44 & 0.44 & 0.36 & 0.29 \\
\hline & Shrinking & 0.27 & 0.69 & 0.58 & 0.38 & 0.20 & 0.30 & 0.26 & 0.36 & 0.34 & 0.22 & 0.20 \\
\hline \multicolumn{13}{|l|}{$\overline{\text { GDP }}$} \\
\hline & Growing & 0.58 & 0.44 & 0.56 & 0.56 & 0.60 & 0.48 & 0.58 & 0.56 & 0.48 & 0.60 & 0.71 \\
\hline & Shrinking & 0.42 & 0.56 & 0.44 & 0.44 & 0.40 & 0.52 & 0.42 & 0.44 & 0.52 & 0.40 & 0.29 \\
\hline
\end{tabular}

Source: Derived from Broadberry et al. (2015). 
Table 11: British Sectoral Data Base: Average rate of change of output in all years, growing years and shrinking years

\begin{tabular}{|c|c|c|c|c|c|c|c|c|c|c|c|c|}
\hline & & $\begin{array}{r}1270- \\
1348 \\
\end{array}$ & $\begin{array}{r}1348- \\
1400\end{array}$ & $\begin{array}{r}1400- \\
1450\end{array}$ & $\begin{array}{r}1450- \\
1500\end{array}$ & $\begin{array}{r}1500- \\
1550\end{array}$ & $\begin{array}{r}1550- \\
1600\end{array}$ & $\begin{array}{r}1600- \\
1650\end{array}$ & $\begin{array}{r}1650- \\
1700\end{array}$ & $\begin{array}{r}1700- \\
1750\end{array}$ & $\begin{array}{r}1750- \\
1800\end{array}$ & $\begin{array}{r}1800- \\
1870 \\
\end{array}$ \\
\hline Agriculture & Growing & 8.30 & 8.92 & 7.69 & 5.92 & 7.04 & 17.77 & 12.21 & 14.82 & 11.92 & 6.51 & 7.45 \\
\hline \multirow[t]{3}{*}{ Industry } & All years & 0.11 & -0.70 & -0.35 & 0.32 & 0.86 & 0.75 & 0.24 & 1.26 & 0.59 & 1.47 & 2.67 \\
\hline & Growing & 4.70 & 5.44 & 4.17 & 2.39 & 1.59 & 5.32 & 3.57 & 6.45 & 6.20 & 4.17 & 5.42 \\
\hline & Shrinking & -5.83 & -6.84 & -4.52 & -2.77 & -1.71 & -3.48 & -5.19 & -5.34 & -6.54 & -3.32 & -4.23 \\
\hline Services & Shrinking & -1.04 & -2.59 & -1.21 & -1.60 & -0.55 & -0.90 & -0.88 & -1.37 & -2.05 & -2.31 & -2.41 \\
\hline \multirow[t]{3}{*}{ GDP } & All years & 0.16 & -0.97 & -0.22 & 0.31 & 0.58 & 0.66 & 0.20 & 1.02 & 0.53 & 1.20 & 2.07 \\
\hline & Growing & 4.40 & 5.48 & 4.12 & 3.21 & 2.88 & 8.59 & 5.54 & 7.10 & 5.21 & 2.96 & 3.70 \\
\hline & Shrinking & -5.61 & -6.08 & -5.74 & -3.38 & -2.87 & -6.65 & -7.18 & -6.71 & -3.79 & -1.46 & -2.02 \\
\hline
\end{tabular}

Source: Derived from Broadberry et al. (2015). 
Table 12: British Sectoral Data Base: Contributions of growing (frequency* ${ }^{*}$ rate) and shrinking (frequency* rate) to long run economic performance (average rate of change of output in all years)

\begin{tabular}{|c|c|c|c|c|c|c|c|c|c|c|c|c|}
\hline & & $\begin{array}{r}1270- \\
1348 \\
\end{array}$ & $\begin{array}{r}1348- \\
1400 \\
\end{array}$ & $\begin{array}{r}1400- \\
1450 \\
\end{array}$ & $\begin{array}{r}1450- \\
1500 \\
\end{array}$ & $\begin{array}{r}1500- \\
1550 \\
\end{array}$ & $\begin{array}{r}1550- \\
1600 \\
\end{array}$ & $\begin{array}{r}1600- \\
1650 \\
\end{array}$ & $\begin{array}{r}1650- \\
1700 \\
\end{array}$ & $\begin{array}{r}1700- \\
1750 \\
\end{array}$ & $\begin{array}{r}1750- \\
1800 \\
\end{array}$ & $\begin{array}{r}1800- \\
1870 \\
\end{array}$ \\
\hline \multirow[t]{3}{*}{ Agriculture } & All years & 0.12 & -0.89 & -0.13 & 0.23 & 0.29 & 0.66 & -0.36 & 0.91 & 0.49 & 0.91 & 0.92 \\
\hline & Growing & 4.36 & 4.46 & 4.31 & 3.20 & 3.52 & 8.53 & 6.35 & 7.70 & 5.48 & 3.52 & 3.83 \\
\hline & Shrinking & -4.24 & -5.35 & -4.43 & -2.96 & -3.23 & -7.87 & -6.71 & -6.80 & -4.99 & -2.61 & -2.91 \\
\hline \multirow[t]{3}{*}{ Industry } & All years & 0.11 & -0.70 & -0.35 & 0.32 & 0.86 & 0.75 & 0.24 & 1.26 & 0.59 & 1.47 & 2.67 \\
\hline & Growing & 2.65 & 2.72 & 2.00 & 1.43 & 1.24 & 2.55 & 2.21 & 3.61 & 3.47 & 2.67 & 3.87 \\
\hline & Shrinking & -2.54 & -3.42 & -2.35 & -1.11 & -0.38 & -1.81 & -1.97 & -2.35 & -2.88 & -1.20 & -1.21 \\
\hline \multirow[t]{3}{*}{ Services } & All years & 0.29 & -1.45 & -0.20 & 0.43 & 0.55 & 0.54 & 0.88 & 0.84 & 0.51 & 1.28 & 2.17 \\
\hline & Growing & 0.57 & 0.35 & 0.51 & 1.03 & 0.66 & 0.81 & 1.11 & 1.34 & 1.20 & 1.79 & 2.65 \\
\hline & Shrinking & -0.28 & -1.80 & -0.70 & -0.61 & -0.11 & -0.27 & -0.23 & -0.49 & -0.70 & -0.51 & -0.48 \\
\hline \multirow[t]{3}{*}{ GDP } & All years & 0.16 & -0.97 & -0.22 & 0.31 & 0.58 & 0.66 & 0.20 & 1.02 & 0.53 & 1.20 & 2.07 \\
\hline & Growing & 2.54 & 2.42 & 2.30 & 1.80 & 1.73 & 4.12 & 3.21 & 3.98 & 2.50 & 1.78 & 2.64 \\
\hline & Shrinking & -2.37 & -3.39 & -2.52 & -1.49 & -1.15 & -3.46 & -3.02 & -2.95 & -1.97 & -0.58 & -0.58 \\
\hline
\end{tabular}

Source: Derived from Broadberry et al. (2015). 
TABLE 13: Shift-share analysis of the contribution of British agriculture to economic performance

A. Sectoral shares and contributions

\begin{tabular}{|c|c|c|c|c|c|c|}
\hline & \multicolumn{2}{|c|}{ Shares } & \multicolumn{2}{|c|}{ Contributions $1270-1348$} & \multicolumn{2}{|c|}{ Contributions $1800-1870$} \\
\hline & 1381 & 1841 & Growing & Shrinking & Growing & Shrinking \\
\hline Agriculture & 0.455 & 0.221 & 4.36 & -4.24 & 3.83 & -2.91 \\
\hline Industry & 0.288 & 0.364 & 2.65 & -2.54 & 3.87 & -1.21 \\
\hline Services & 0.257 & 0.415 & 0.57 & -0.28 & 2.65 & -0.48 \\
\hline Total & 1.000 & 1.000 & 4.36 & -4.24 & 3.83 & -2.91 \\
\hline
\end{tabular}

B. Shift-share analysis

\begin{tabular}{|c|c|c|c|c|c|c|c|c|}
\hline & \multicolumn{2}{|c|}{$\begin{array}{c}1381 \text { shares } \\
1270-1348 \text { contributions }\end{array}$} & \multicolumn{2}{|c|}{$\begin{array}{c}1841 \text { shares } \\
1270-1348 \text { contributions }\end{array}$} & \multicolumn{2}{|c|}{$\begin{array}{c}1381 \text { shares } \\
1800-1870 \text { contributions }\end{array}$} & \multicolumn{2}{|c|}{$\begin{array}{c}1841 \text { shares } \\
1800-1870 \text { contributions }\end{array}$} \\
\hline & Growing & Shrinking & Growing & Shrinking & Growing & Shrinking & Growing & Shrinking \\
\hline & $(1)$ & $(2)$ & (3) & (4) & $(5)$ & $(6)$ & $(7)$ & $(8)$ \\
\hline Agriculture & 1.98 & -1.93 & 0.96 & -0.94 & 1.74 & -1.32 & 0.85 & -0.64 \\
\hline Industry & 0.76 & -0.73 & 0.96 & -0.92 & 1.11 & -0.35 & 1.41 & -0.44 \\
\hline Services & 0.15 & -0.07 & 0.24 & -0.12 & 0.68 & -0.12 & 1.10 & -0.20 \\
\hline Total & 2.89 & -2.73 & 2.16 & -1.98 & 3.54 & -1.80 & 3.35 & -1.28 \\
\hline Net output performance & & 0.16 & & 0.19 & & 1.74 & & 2.07 \\
\hline Actual output performance & & 0.16 & & 0.16 & & 2.07 & & 2.07 \\
\hline
\end{tabular}

Sources and notes: Sectoral shares: Broadberry et al. (2015: 194). Contributions of growing (frequency * growing rate) and shrinking (frequency

* shrinking rate): Table 12. 
TABLE 14: Accounting for British GDP growth, 1760-1913 (\% per annum)

\begin{tabular}{lcccrr}
\hline & $\begin{array}{l}\text { Output } \\
\text { growth }\end{array}$ & $\begin{array}{c}\text { Due to } \\
\text { capital }\end{array}$ & $\begin{array}{l}\text { Due to } \\
\text { labour }\end{array}$ & $\begin{array}{r}\text { Due to } \\
\text { human } \\
\text { capital }\end{array}$ & $\begin{array}{r}\text { TFP } \\
\text { growth }\end{array}$ \\
\hline $1760-1780$ & 0.60 & 0.25 & 0.20 & 0.10 & 0.05 \\
$1780-1831$ & 1.70 & 0.60 & 0.45 & 0.45 & 0.20 \\
$1831-1873$ & 2.40 & 0.90 & 0.45 & 0.70 & 0.35 \\
$1873-1899$ & 2.10 & 0.80 & 0.30 & 0.50 & 0.50 \\
$1899-1913$ & 1.40 & 0.80 & 0.30 & 0.50 & -0.20 \\
\hline
\end{tabular}

Sources and notes: Crafts (1995: 752). The factor weights are 0.4 for capital, 0.35 for labour and 0.25 for human capital.

TABLE 15: Accounting for Dutch GDP growth, 1540-1800 (\% per annum)

\begin{tabular}{rrrrrr}
\hline & $\begin{array}{l}\text { Output } \\
\text { growth }\end{array}$ & $\begin{array}{l}\text { Due to } \\
\text { capital }\end{array}$ & $\begin{array}{l}\text { Due to } \\
\text { labour }\end{array}$ & $\begin{array}{l}\text { Due to } \\
\text { human } \\
\text { capital }\end{array}$ & $\begin{array}{r}\text { TFP } \\
\text { growth }\end{array}$ \\
\hline $1540-1620$ & 1.92 & 0.62 & 0.37 & 0.29 & 0.64 \\
$1620-1665$ & -0.18 & 0.30 & 0.24 & 0.32 & -1.04 \\
$1665-1720$ & 0.08 & -0.10 & -0.01 & 0.14 & 0.05 \\
$1720-1800$ & 0.04 & 0.09 & -0.11 & -0.03 & 0.09 \\
\hline
\end{tabular}

Sources and notes: Derived from van Zanden and van Leeuwen (2012: 126). Weights are 0.4 for capital, 0.35 for labour and 0.25 for human capital. 
FIGURE 4: Vital rates in England 1541-2000 (crude birth rate and crude death rate per 1,000 population)

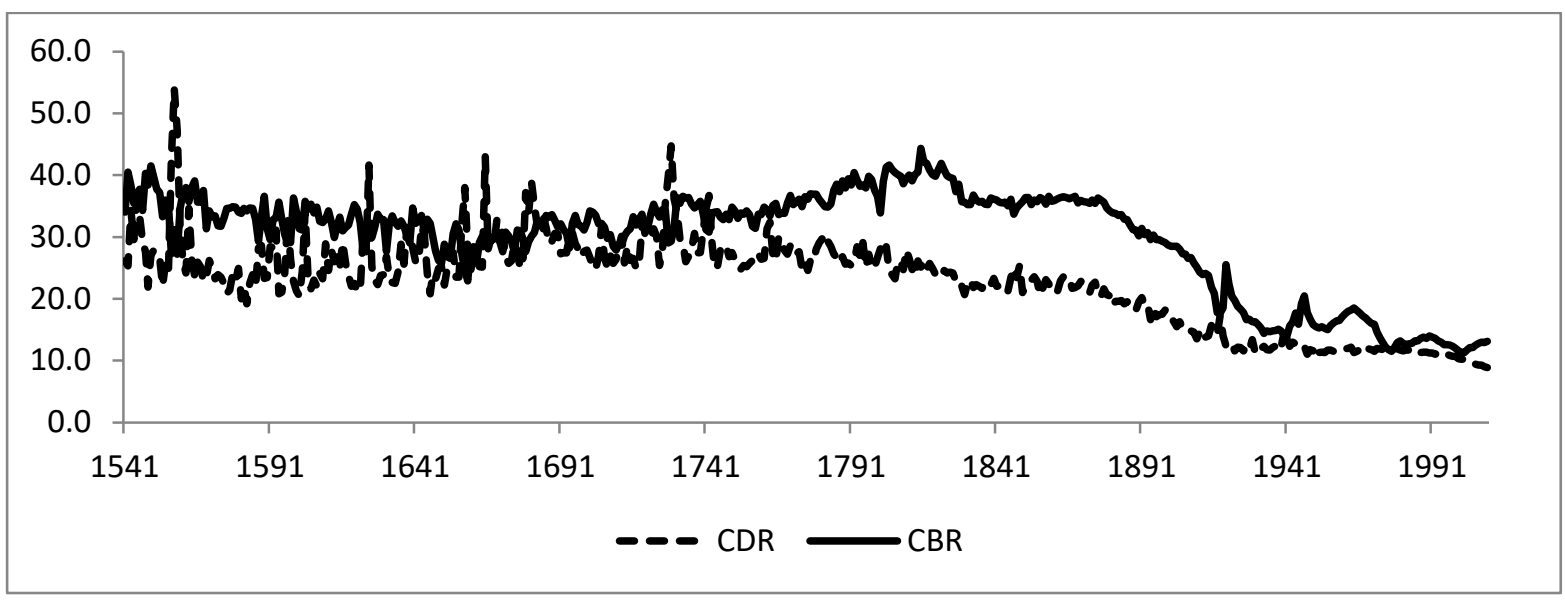

Sources: Wrigley and Schofield (1981); Mitchell (1988); UK Office for National Statistics, http://www.ons.gov.uk/ons/index.html; 
APPENDIX 1: MORE DETAILED DATA ON THE PERIOD 1820-2008

Table A1: Maddison Data Base: Frequency of growing and shrinking, 1820-2008

\begin{tabular}{|c|c|c|c|c|c|}
\hline & & $1820-1870$ & $1870-1910$ & $1910-1950$ & $1950-2008$ \\
\hline \multicolumn{6}{|l|}{ UK } \\
\hline & Growing & 0.73 & 0.60 & 0.70 & 0.86 \\
\hline & Shrinking & 0.27 & 0.40 & 0.30 & 0.14 \\
\hline \multicolumn{6}{|l|}{ Netherlands } \\
\hline & Growing & 0.72 & 0.70 & 0.63 & 0.88 \\
\hline & Shrinking & 0.28 & 0.30 & 0.37 & 0.12 \\
\hline \multicolumn{6}{|l|}{ Italy } \\
\hline & Growing & 0.78 & 0.63 & 0.58 & 0.93 \\
\hline & Shrinking & 0.22 & 0.37 & 0.42 & 0.07 \\
\hline \multicolumn{6}{|l|}{ Spain } \\
\hline & Growing & 0.70 & 0.58 & 0.58 & 0.93 \\
\hline & Shrinking & 0.30 & 0.42 & 0.42 & 0.07 \\
\hline \multirow[t]{2}{*}{$\begin{array}{l}14 \text { European } \\
\text { countries }\end{array}$} & Growing & 0.68 & 0.68 & 0.66 & 0.89 \\
\hline & Shrinking & 0.32 & 0.32 & 0.34 & 0.11 \\
\hline \multicolumn{6}{|l|}{ USA } \\
\hline & Growing & & 0.65 & 0.63 & 0.83 \\
\hline & Shrinking & & 0.35 & 0.37 & 0.17 \\
\hline \multirow[t]{2}{*}{$\begin{array}{l}4 \text { New World } \\
\text { countries }\end{array}$} & Growing & 0.66 & 0.64 & 0.60 & 0.82 \\
\hline & Shrinking & 0.34 & 0.36 & 0.40 & 0.18 \\
\hline \multirow{3}{*}{$\begin{array}{l}18 \text { European } \\
\& \text { New World } \\
\text { countries }\end{array}$} & & & & & \\
\hline & Growing & 0.66 & 0.67 & 0.65 & 0.88 \\
\hline & Shrinking & 0.34 & 0.33 & 0.35 & 0.12 \\
\hline
\end{tabular}

Sources and notes: Derived from Maddison (2010). The other included European countries are: Belgium, France, Switzerland, Austria, Germany, Portugal, Finland, Denmark, Norway and Sweden/ The other included New World countries are: Australia, New Zealand and Canada. 
Table A2: Maddison Data Base: Average rate of change of per capita income in all years, growing years and shrinking years

\begin{tabular}{llrrrr}
\hline & & $1820-1870$ & $1870-1910$ & $1910-1950$ & $1950-2008$ \\
\hline UK & All years & 1.50 & 0.92 & 1.02 & 2.12 \\
& Growing & 2.72 & 2.37 & 3.17 & 2.61 \\
& Shrinking & -1.70 & -1.25 & -3.99 & -0.96 \\
\hline Netherlands & All years & 0.81 & 0.79 & 1.15 & 2.44 \\
& Growing & 1.70 & 2.28 & 6.47 & 2.92 \\
& Shrinking & -1.48 & -2.67 & -7.72 & -1.06 \\
\hline Italy & All years & 0.39 & 1.10 & 1.02 & 3.00 \\
& Growing & 2.22 & 3.54 & 6.27 & 3.31 \\
& Shrinking & -6.00 & -2.95 & -6.09 & -1.27 \\
\hline Spain & All years & 0.56 & 1.13 & 0.36 & 3.79 \\
& Growing & 2.32 & 4.25 & 3.60 & 4.18 \\
& Shrinking & -3.55 & -3.10 & -4.03 & -1.46 \\
\hline 14 European & All years & 1.22 & 1.23 & 1.26 & 2.70 \\
countries & Growing & 3.51 & 2.83 & 5.35 & 3.18 \\
& Shrinking & -2.80 & -1.94 & -6.78 & -1.18 \\
\hline USA & All years & & 1.77 & 1.64 & 2.04 \\
& Growing & & 4.30 & 6.49 & 2.77 \\
& Shrinking & & -2.93 & -6.44 & -1.49 \\
\hline 4 New World & All years & 3.69 & 1.62 & 1.29 & 1.92 \\
countries & Growing & 8.74 & 4.67 & 5.52 & 2.73 \\
& Shrinking & -6.13 & -3.88 & -5.20 & -1.68 \\
\hline 18 European & All years & 1.40 & 1.31 & 1.23 & 2.55 \\
\& New World & Growing & 3.88 & 3.16 & 5.20 & 3.06 \\
countries & Shrinking & -3.04 & -2.30 & -6.10 & -1.23 \\
\hline
\end{tabular}

Sources and notes: Derived from Maddison (2010). The other included European countries are: Belgium, France, Switzerland, Austria, Germany, Portugal, Finland, Denmark, Norway and Sweden/ The other included New World countries are: Australia, New Zealand and Canada. 
Table A3: Maddison Data Base: Contributions of growing (frequency*rate) and shrinking (frequency* rate) to long run economic performance (average rate of change of per capita income in all years)

\begin{tabular}{llrrrr}
\hline & & $1820-1870$ & $1870-1910$ & $1910-1950$ & $1950-2008$ \\
\hline UK & All years & 1.50 & 0.92 & 1.02 & 2.12 \\
& Growing & 1.97 & 1.42 & 2.22 & 2.25 \\
& Shrinking & -0.47 & -0.50 & -1.20 & -0.13 \\
\hline Netherlands & All years & 0.81 & 0.79 & 1.15 & 2.44 \\
& Growing & 1.23 & 1.59 & 4.04 & 2.57 \\
& Shrinking & -0.42 & -0.80 & -2.90 & -0.13 \\
\hline Italy & All years & 0.39 & 1.10 & 1.02 & 3.00 \\
& Growing & 1.73 & 2.21 & 3.61 & 3.08 \\
& Shrinking & -1.33 & -1.11 & -2.59 & -0.09 \\
\hline Spain & All years & 0.56 & 1.13 & 0.36 & 3.79 \\
& Growing & 1.63 & 2.45 & 2.07 & 3.89 \\
& Shrinking & -1.07 & -1.32 & -1.71 & -0.10 \\
\hline 14 European & All years & 1.22 & 1.23 & 1.26 & 2.70 \\
countries & Growing & 2.22 & 1.88 & 3.49 & 2.84 \\
& Shrinking & -1.00 & -0.65 & -2.24 & -0.14 \\
\hline USA & All years & & 1.77 & 1.64 & 2.04 \\
& Growing & & 2.80 & 4.05 & 2.29 \\
& Shrinking & & -1.03 & -2.42 & -0.26 \\
\hline New World & All years & 3.69 & 1.62 & 1.29 & 1.92 \\
& Growing & 5.77 & 3.01 & 3.31 & 2.24 \\
& Shrinking & -2.08 & -1.39 & -2.03 & -0.32 \\
\hline 18 European & All years & 1.40 & 1.31 & 1.23 & 2.55 \\
\& New World \\
countries & Growing & 2.47 & 2.10 & 3.33 & 2.72 \\
& Shrinking & -1.08 & -0.79 & -2.09 & -0.16 \\
\hline
\end{tabular}

Sources and notes: Derived from Maddison (2010). The other included European countries are: Belgium, France, Switzerland, Austria, Germany, Portugal, Finland, Denmark, Norway and Sweden/ The other included New World countries are: Australia, New Zealand and Canada. 


\section{REFERENCES}

Allen, Robert C. (2009), “The Industrial Revolution in Miniature: The Spinning Jenny in Britain, France, and India”, Journal of Economic History, 69, 901-927.

Álvarez-Nogal, Carlos and Leandro Prados de la Escosura (2013), "The Rise and Fall of Spain (1270-1850)", Economic History Review, 66, 1-37.

Ashton, Thomas S. [1948] (1968), The Industrial Revolution 1760-1830, Oxford: Oxford University Press.

Bolt, Jutta and Jan Luiten van Zanden (2014), The Maddison Project: A Collaborative Data Base, Economic History Review, 67, 627-651.

Broadberry, Stephen (1997), The Productivity Race: British Manufacturing in International Perspective, 1850-1990, Cambridge: Cambridge University Press.

Broadberry, Stephen (2013), "Accounting for the Great Divergence", Economic History Working Papers, 184/13. London School of Economics and Political Science, http://eprints.1se.ac.uk/54573/.

Broadberry, Stephen, Bruce M.S. Campbell, Alexander Klein, Mark Overton and Bas van Leeuwen (2015), British Economic Growth, 1270-1870, Cambridge: Cambridge University Press.

Broadberry, Stephen and Mark Harrison (2008), "Economics of the World Wars", in Durlauf, Steven N. and Lawrence Blume (eds.), New Palgrave Dictionary of Economics, Second Edition, New York: Palgrave Macmillan.

Broadberry, Stephen and John Wallis (2016), "Shrink Theory: The Nature of Economic Performance in the Long- and Short-Run", Nuffield College, Oxford and University of Maryland.

Clark, Gregory (2007), A Farewell to Alms: A Brief Economic History of the World, Princeton: Princeton University Press.

Crafts, Nicholas F.R. (1995), "Exogenous or Endogenous Growth?: The Industrial Revolution Reconsidered", Journal of Economic History, 55, 745-772.

Crafts, Nicholas F.R. and C. Knick Harley (1992), "Output Growth and the Industrial Revolution: A Restatement of the Crafts-Harley View", Economic History Review, $45,703-730$.

Cuberes, David and Michael Jerzmanowski (2009), "Democracy, Diversification and Growth Reversals", Economic Journal, 119, 1270-1302.

Easterly, William, Michael Kremer, Lant Pritchett and Lawrence H. Summers (1993), "Good Policy or Good Luck?," Journal of Monetary Economics, 32, 459-483. 
Feenstra, Robert C., Robert Inklaar, and Marcel P. Timmer (2015), "The Next Generation of the Penn World Table", American Economic Review, 105, 3150-3182.

Feinstein, Charles H. (1988), "National Statistics, 1760-1920: Sources and Methods of Estimation for Domestic Reproducible Fixed Assets, Stocks and Works in Progress, Overseas Assets, and Land", in Feinstein, Charles H. and Sidney Pollard (eds.), Studies in Capital Formation in the United Kingdom, 1750-1920, Oxford: Oxford University Press, 257-471.

Fouquet, Roger and Stephen Broadberry (2015), "Seven Centuries of European Economic Growth and Decline", Journal of Economic Perspectives, 29, 227-244 (with Roger Fouquet).

Galor, Oded (2005), "From Stagnation to Growth: Unified Growth Theory", in Aghion, P. and Durlauf, S.N. (ed.), Handbook of Economic Growth, Volume 1A, Amsterdam: Elsevier, 171-285.

Galor, Oded and Weil, David N. (2000), Population, Technology and Growth: From the Malthusian Regime to the Demographic Transition", American Economic Review, 90, 806-828.

Hartwell, Robert (1966), "Markets, Technology, and the Structure of Enterprise in the Development of the Eleventh-century Chinese Iron and Steel Industry", Journal of Economic History, 26, 29-58.

Hills, S., Thomas, R. and Dimsdale, N. (2010), "The UK Recession in Context - What do Three Centuries of Data Tell Us?”, Bank of England Quarterly Bulletin, 277-291.

Hoffman, Philip T. (2015), Why Did Europe Conquer the World?, Princeton: Princeton University Press.

Jones, Eric (1981), The European Miracle: Environments, Economies and Geopolitics in the History of Europe and Asia, Cambridge: Cambridge University Press.

Kahn, B. Zorina. (2005), The Democratization of Invention: Patents and Copyrights in American Economic Development, 1790-1920, Cambridge: Cambridge University Press.

Maddison, Angus (1988), Ultimate and Proximate Growth Causality: A Critique of Mancur Olson on the Rise and Decline of Nations", Scandinavian Economic History Review, $36,25-29$.

Maddison, Angus (1991), Dynamic Forces in Capitalist Development: A Long-Run Comparative View, Oxford: Oxford University Press.

Maddison, Angus (2001), The World Economy: A Millennial Perspective, Paris: Organisation for Economic Co-operation and Development.

Maddison, Angus (2010), "Statistics on World Population, GDP and Per Capita GDP, 1-2008 AD", Groningen Growth and Development Centre, 
http://www.ggdc.net/MADDISON/oriindex.htm.

Malanima, Paolo (2011), "The Long Decline of a Leading Economy: GDP in Central and Northern Italy, 1300-1913”, European Review of Economic History, 15, 169-219.

Malthus, T.R. [1798] (1970), An Essay on the Principle of Population, as it Affects the Future Improvement of Society with Remarks on the Speculations of Mr Godwin, M. Condorcet, and Other Writers, Harmondsworth: Penguin.

Matthews, R.C.O., Feinstein, C.H. and Odling-Smee, J.C. (1982), British Economic Growth, 1856-1973, Oxford: Clarendon.

Mitchell, Brian R. (1988), British Historical Statistics, Cambridge: Cambridge University Press.

North, Douglass C. (1961), The Economic

Growth of the United States 1790-1860, Englewood Cliffs, NJ: Prentice-Hall.

North, Douglass C. (1990), Institutions, Institutional Change and Economic Performance, Cambridge: Cambridge University Press.

North, Douglass C., John J. Wallis and Barry R. Weingast (2009), Violence and Social Orders: A Conceptual Framework for Interpreting Recorded Human History, Cambridge: Cambridge University Press.

North, Douglass C. and Barry R. Weingast (1989), "Constitutions and Commitment: The Evolution of Institutions Governing Public Choice in Seventeenth-Century England", Journal of Economic History, 49, 803-832.

Penn World Table 8.0, http://www.rug.nl/research/ggdc/data/pwt/pwt-8.0.

Pinker, Steven (2011), The Better Angels of Our Nature: Why Violence Has Declined, New York: Penguin.

Pritchett, Lant (1997), “Divergence, Big Time”, Journal of Economic Perspectives, 11(3), 317.

Pritchett, Lant (2000), "Understanding Patterns of Economic Growth: Searching for Hills among Plateaus, Mountains and Plains”, World Bank Economic Review, 14, 221-250.

Reader, William J. (1970), ICI: A History, Volume I: The Forerunners 1870-1926, Oxford; Oxford University Press.

Reader, William J. (1975), ICI: A History, Volume II: The First Quarter-Century 1926-1952, Oxford; Oxford University Press.

Rodrik, Dani (1999), "Where Did All the Growth Go? External Shocks, Social Conflict, and Growth Collapses", Journal of Economic Growth, 4, 358-412,

Smith, Adam [1776] (1976), The Wealth of Nations, Harmondsworth: Penguin. 
Solar, Peter M. (1995), "Poor Relief and English Economic Development before the Industrial Revolution", Economic History Review 48, 1-22.

Tilly, Charles (1990), Coercion, Capital, and European States, AD 990-1990. Cambridge, Mass.: Blackwell.

Tranter, Neil L. (1996), British Population in the Twentieth Century, Basingstoke: Macmillan.

UK Office for National Statistics (2015), Data, http://www.ons.gov.uk/ons/index.html.

Urlanis, Boris (1971), Wars and Population, Moscow: Progress Publishers.

Voigtländer, Nico and Hans-Joachim Voth (2013a), "The Three Horsemen of Riches: Plague, War, and Urbanization in Early Modern Europe", Review of Economic Studies, 80, 774-811.

Voigtländer, Nico and Hans-Joachim Voth (2013b), "Gifts of Mars: Warfare and Europe's Early Rise to Riches", Journal of Economic Perspectives, 27, 165-186.

Voigtländer, Nico and Hans-Joachim Voth (2013c), "How the West 'Invented' Fertility Restriction", American Economic Review, 103, 2227-2264.

Wallis, John Joseph (2011), "Institutions, Organizations, Impersonality, and Interests: The Dynamics of Institutions," Journal of Economic Behavior and Organization,

Wallis, John Joseph (2016), "The New Economic History and Beyond: The Scholarship of Douglass C. North. Journal of Economic History. September, 2016.

Wrigley, E. Anthony, and Roger S. Schofield (1981), The Population History of England, 1541-1871: A Reconstruction, Cambridge: Cambridge University Press.

van Zanden, Jan Luiten and Bas van Leeuwen (2012), "Persistent but not Consistent: The Growth of National Income in Holland, 1347-1807", Explorations in Economic History, 49, 119-130. 